\title{
Immunological phenomena in the jejunum and serum after reintroduction of dietary gluten in children with treated coeliac disease
}

\author{
M. LANCASTER-SMITH, SUSAN PACKER, PARVEEN J. KUMAR, AND J. T. \\ HARRIES
}

From the Hospital for Sick Children, Great Ormond Street and Institute of Child Health, Guilford Street, London WC1, and the Department of Gastroenterology, St. Bartholomew's Hospital, London ECI

SYNOPSIS Jejunal mucosal immunoglobulin-containing cells of all three major classes (IgA, IgM, IgG) were increased in coeliac children on gluten-containing diets but only IgM cell numbers werev raised in those on gluten-free diets. Patients with subtotal villous atrophy had greater numbers of 9 immunoglobulin-containing cells than patients with normal mucosa. In previously treated patients studied before and after three months on a gluten-containing diet there was an increase in all three classes of cell, IgM containing cells showing the greatest proportional rise.

Basement membrane staining with anti-IgA serum occurred in coeliacs and was most intense in untreated patients. Apart from one patient with very low levels of serum $\operatorname{IgA}$, serum immunoglobulins did not differ from normal. However, after reintroduction of gluten to the diet a significanto fall in serum IgM concentrations occurred compared with levels in the same patients while on gluten-free diets. It seems probable that both IgA and IgM systems are important in the immuno-a pathogenesis of the small intestinal lesion of childhood coeliac disease.

Immunoglobulin and complement aggregation in the jejunal mucosa and changes in serum complement concentrations have been demonstrated after a single-dose gluten challenge in both adult (Doe et al, 1974) and childhood coeliac disease (Shiner and Ballard, 1972; McNeish et al, 1974). Abnormal populations of jejunal mucosal immunoglobulincontaining cells detected by immunohistochemical techniques occur in both adults (Douglas et al, 1970; Soltoft, 1970; Pettingale, 1971; Lancaster-Smith et al, 1974b) and children (Savilahti, 1972b) with coeliac disease and, when standard histological methods are used, increased numbers of plasma cells are found in the small intestinal mucosa of coeliac patients (Holmes et al, 1974; Lancaster-Smith et al, 1975). These findings suggest that humoral immunological phenomena are involved in the pathogenesis of the intestinal lesion.

The purpose of the present study was to investigate immunological changes in the jejunal mucosa and serum of treated coeliac children induced by a more prolonged re-exposure of the small intestine togluten

Received for publication 10 December 1975 in order to obtain information not previously? available about intermediate stages in the immunopathogenesis of childhood coeliac disease.

\section{Patients and methods}

In the group of patients studied, a past diagnosis of coeliac disease had been based on suggestive clinical ${ }_{\circ}$ and biochemical evidence but without jejunal biopsy? confirmation. The children have been managed on a음 gluten-free diet and the majority were continuing on this regime at the time of study. Because of this $N$ unsatisfactory basis for the original diagnosis, and 0 in order to advise on a rational future treatment, it was necessary to confirm or exclude the diagnosis of ${ }^{\mathcal{\omega}}$ coeliac disease by jejunal biopsy. This, in most instances, required appraisal of jejunal morphology after reintroduction of gluten to the diet.

PATIENTS

Twenty-two children who had previously been $\frac{\bar{O}}{\Phi}$ tenuously diagnosed as having coeliac disease $\frac{\rho}{+}$ without histological confirmation between the ages of 0.5 and 5 years, mean 2 years, were included in 592 
the study, at which time the mean age was 11.5 years, range 5-16.5 years. A thorough assessment of the diet was made in all patients by the same dietitian. Sixteen had been on a gluten-free diet from 1.5 to 13 years, mean 6.9 years, and six admitted to consuming varying amounts of gluten immediately before this study for three months to 12 years, mean $5 \cdot 3$ years. Jejunal biopsies and sera from each of the 22 children were obtained at the beginning of the investigation. If the initial biopsy showed villous atrophy the diagnosis of coeliac disease was accepted. If in contrast the first biopsy was normal, the patient was instructed to take a diet containing at least $10 \mathrm{~g}$ of gluten as natural wheat protein per day for a period of three months, after which the patient was investigated again. Thus, in 16 children biopsies were obtained while on gluten-free and after three months on gluten-containing diets. All 16 pairs of biopsies were suitable for routine histology and 13 for immunofluorescent microscopy. Paired sera were available from 15 subjects.

\section{METHODS}

Jejunal biopsies were obtained by Crosby Capsule in fasting subjects from the duodenojejunal flexure under fluoroscopic control. Tissue was processed for both routine histology and immunofluorescent microscopy (Lancaster-Smith et al, 1974b) using antisera to human IgA, IgM, IgG, and the third component of complement conjugated with fluoresceine isothiocyanate (Behringwerke). The numbers of immunofluorescent cells of each immunoglobulin class were estimated by a direct counting technique (Savilahti, 1972b) over an area of $0.5 \mathrm{~mm}^{2}$ between the epithelium and muscularis mucosae. The presence and degree of staining of the luminal surface and basement membrane region of the epithelial cell layer were graded using the method of Shiner and Ballard (1972). Serum concentrations of immunoglobulins ( $\operatorname{IgA}, \operatorname{IgG}, \operatorname{IgM})$ were estimated by single radial immunodiffusion. Paired and unpaired Student $t$ tests were used, where appropriate, for statistical analysis.

\section{Results}

JEJUNAL MORPHOLOGY

Of the six subjects who were on a gluten-containing diet, two had villous atrophy (villous heights 0 and 120 microns) and have coeliac disease, while the remaining four had completely normal villous morphology (villous heights mean \pm SE $387 \pm 15 \cdot 7$ microns), excluding the diagnosis of coeliac disease. Of the 16 patients on an alleged gluten-free diet, 13 had a normal initial biopsy but after three months on a gluten-containing diet 10 of these had significant villous atrophy (villous heights, mean \pm SE $119 \pm$ 28.5 microns) and therefore have proven coeliac disease. Three, however, remained normal (villous heights, mean \pm SE $444 \pm 23.5$ microns) and have continued to show no evidence of coeliac disease after 24 months on a substantial daily intake of gluten. The other three patients with abnormal villous morphology (villous heights, mean $\pm \mathrm{SE}$ $212 \pm 65.7$ microns) while on alleged gluten-free diets, which on further investigation were found to contain small amounts of gluten, showed increased morphological deterioration of the jejunum after three months on the $10 \mathrm{~g}$ gluten per day diet (villous heights, mean \pm SE $120 \pm 62$ microns). Therefore, of the 22 subjects studied, 15 had proven coeliac disease based on the jejunal mucosal response to gluten. The remaining seven had a normal mucosa and no clinical or biochemical evidence of coeliac disease even after a substantial intake of gluten ranging from 24 months to 12 years. The cause of these subjects' past gastrointestinal symptoms is not known but they clearly do not have coeliac disease. In view of their completely normal jejunal morphology, subsequent good health, and in particular the absence of gastrointestinal disturbance for many years before this study, it was considered reasonable to accept these subjects as controls.

\section{IMMUNOFLUORESCENT STUDIES}

Details of immunoglobulin-containing cells in the jejunal lamina propria are shown in figs 1-3 and table I.

\section{$\operatorname{Ig} A$ cells}

The number of IgA cells in coeliac patients on glutenfree diets did not differ significantly from that in the controls. In contrast, the number of IgA-containing cells in patients on gluten-containing diets were significantly greater than in the controls $(P<0.05)$. In addition the 10 coeliacs studied serially showed a significant increase in the numbers of $\operatorname{IgA}$ cells after three months on a gluten-containing diet $(\mathrm{P}<0.01)$. In general, IgA cells bore no relation to serum concentrations of $\operatorname{IgA}$, but one patient with very low levels of serum $\operatorname{IgA}$ had the fewest $\operatorname{IgA}$ cells in the jejunal mucosa. Excluding this patient with $\operatorname{IgA}$ deficiency, greater numbers of $\operatorname{IgA}$ cells occurred in biopsies with villous atrophy than in coeliac biopsies with normal morphology $(P<0.01)$.

\section{IgG cells}

The number of these cells in coeliac patients on gluten-free diets did not differ significantly from that in the controls. In contrast, the numbers in patients on gluten-containing diets were significantly greater than in the controls $(P<0.002)$, and in the 10 coeliacs 


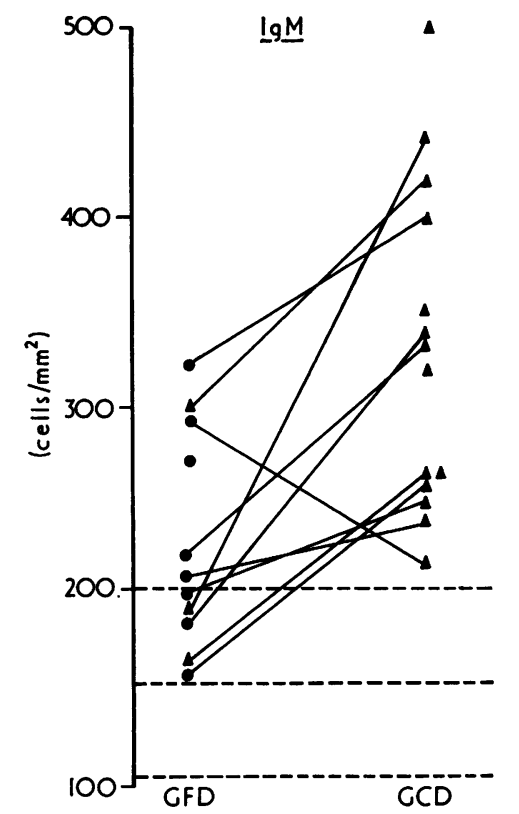

Fig 1

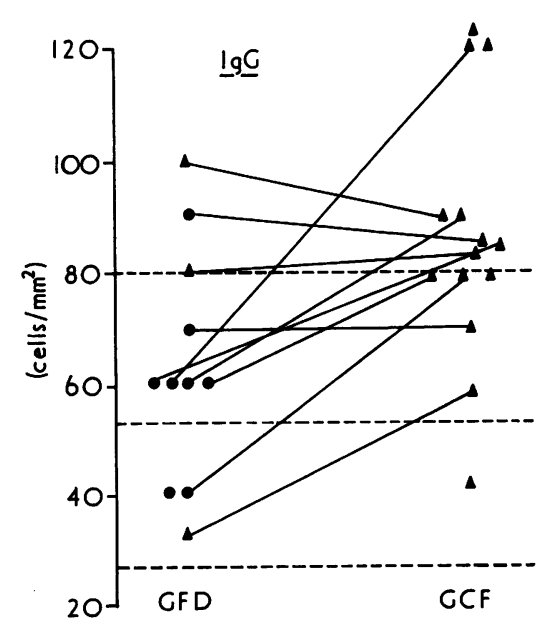

Fig 2

studied serially there was an increase after three months on a gluten-containing $\operatorname{diet}(P<0.05)$. More cells were found in patients with villous atrophy than in coeliacs with normal morphology $(\mathrm{P}<0.05)$.

IgM cells

In contrast to IgA and IgG containing cells, the

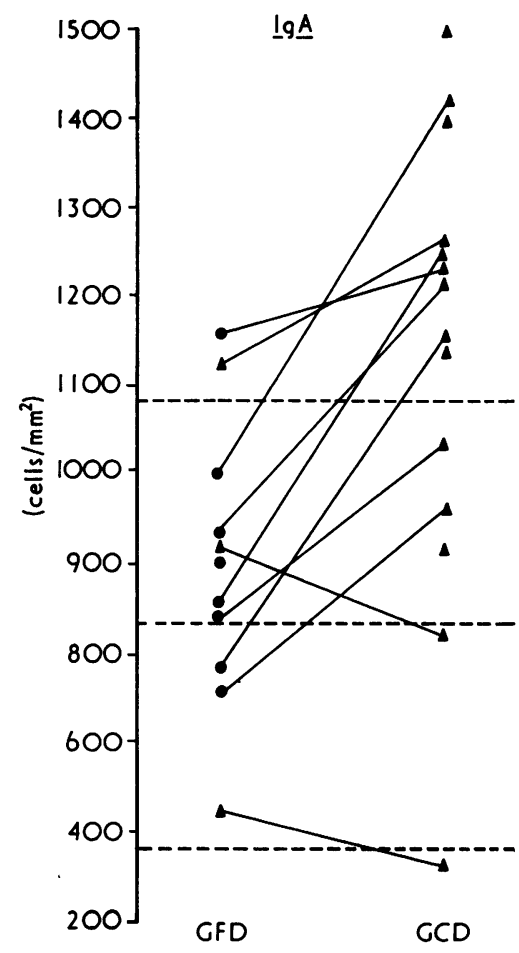

Fig 3

Figs 1-3 Immunoglobulin-containing cells in the jejunal lamina propria in coeliac patients on gluten-free (GFD) and gluten-containing (GCD) diets. The horizontal dotted lines are the control means $\pm 2 S D ; \bigcirc$ normal mucosa; $\Delta$ villous atrophy.

numbers of IgM cells were greater than in controlsi even in coeliacs on gluten-free diets $(P<0.01)$. Just 3 as with IgA and IgG, IgM cells were also significantlyo increased in coeliac patients on gluten-containing diets compared with controls ( $P<0.002$ ). In the 10 吾 patients studied serially there was an increase in IgM cells after three months on a gluten-containingo diet $(P<0.01)$. Greater numbers of IgM cells $N$ occurred in biopsies with villous atrophy than in N coeliac biopsies with normal morphology $(P<0.05)$.

In coeliacs on both gluten-free and gluten-containing diets the numbers of jejunal mucosal im -0 munoglobulin-containing cells of all classes bore now relation to age or to the length of time a patient had been on either type of diet.

In the three serially studied subjects who hado normal jejunal morphology after three months on aे gluten-containing diet there was no significant change in any immunoglobulin class of cell (table 1)? 


\begin{tabular}{lrrll}
\hline & No & \multicolumn{1}{l}{ IgA } & IgM & IgG \\
\hline Coeliac & & & & \\
$\quad$ No gluten & 10 & $896 \pm 52$ & $227 \pm 19$ & $65 \pm 7$ \\
$\begin{array}{c}\text { Gluten } \\
\text { Controls }\end{array}$ & 10 & $1089 \pm 80$ & $314 \pm 26$ & $84 \pm 5$ \\
$\quad \begin{array}{l}\text { No gluten } \\
\quad \text { Gluten }\end{array}$ & 3 & $777 \pm 48$ & $160 \pm 9$ & $50 \pm 8$ \\
$\begin{array}{c}\text { Controls } \\
\text { (Total) }\end{array}$ & $10^{1}$ & $832 \pm 40$ & $151 \pm 10$ & $53 \pm 4$ \\
\hline
\end{tabular}

Table I Jejunal immunoglobulin-containing cells in coeliac and control children before and after reintroduction of dietary gluten

Cells $/ \mathrm{mm}^{2}$ means $\pm \mathrm{SE}$

${ }^{2} 10$ biopsies from 7 subjects

EPITHELIAL CELL AND BASEMENT MEMBRANE STAINING

Intense staining of the apical region of the epithelial cells by anti-IgA serum was seen in the majority of biopsies from both patients and controls. Staining of this region with either anti-IgG or anti-IgM serum occurred only rarely in coeliac biopsies and never in control subjects.

The basement membrane region was stained by anti-IgA serum in the majority of coeliac patients, being most intense in those on gluten-containing diets, but not in controls. No basement membrane region staining was seen with either anti-IgG or anti-IgM sera.

No staining in any region was seen in either coeliac or control biopsies using antisera to the third component of complement.

\section{SERUM IMMUNOGLOBULINS (table II)}

Concentrations of IgA, IgG, and IgM in coeliac patients on either gluten-free or gluten-containing diets did not differ from those in controls. One patient had very low levels of IgA both before $(4 \mathrm{iu} / 100 \mathrm{ml})$ and after $(14 \mathrm{iu} / 100 \mathrm{ml})$ reintroduction of gluten to the diet. In patients studied serially, after three months on a gluten-containing diet there was no significant change in concentrations of $\operatorname{IgA}$ and $\operatorname{IgG}$, but IgM levels fell significantly $(P<0.01$; table II). For all classes of immunoglobulins there was no correlation between the concentrations in the serum and the numbers of jejunal immunoglobulin-containing cells nor between changes in serum immunoglobulin levels and alterations in jejunal immunoglobulin-containing cells after reintroduction of gluten to the diet.

\section{Discussion}

The study confirms in children (Savilahti, 1972a) as in adults (Crabbé et al, 1965; Crabbé and Heremans, 1966; Soltoft, 1969; Lancaster-Smith et al, 1974a, b)

\begin{tabular}{lrrll}
\hline & No & \multicolumn{1}{l}{ IgA } & IgG & IgM \\
\hline Controls & 8 & $97 \pm 13$ & $119 \pm 7$ & $134 \pm 14$ \\
Coeliacs & & $102 \pm 13^{1}$ & $115 \pm 15$ & $158 \pm 15$ \\
$\begin{array}{l}\text { No gluten } \\
\text { Gluten }\end{array}$ & 12 & $117 \pm 27^{1}$ & $110 \pm 11$ & $125 \pm 14$ \\
\hline
\end{tabular}

Table II Serum immunoglobulin concentrations in serially studied coeliacs and controls

IU/100 ml means $\pm \mathrm{SE}$

${ }^{1}$ Patient with IgA deficiency not included

that the order of predominance of immunoglobulincontaining cells in the jejunal lamina propria is IgA $>$ IgM $>$ IgG. In the only two studies which expressed cell numbers per square millimetre (Lancaster-Smith et al, 1974a; Savilahti, 1972a), absolute numbers of cells were closely comparable to those in the present study (table III). These results also demonstrate that children between the ages of 5 and 16 years have immunoglobulincontaining cell populations very similar to those in adults.

The present study confirms the increase of $\operatorname{IgA}$, IgM, and IgG containing cells in coeliac children on gluten-containing diets found by Savilahti (1972b). His untreated patients, however, had even greater numbers of $\operatorname{IgA}$ and IgM cells than our patients. This is almost certainly because they were studied at initial diagnosis before any treatment whereas our patients had previously been on gluten-free diets for long periods and in the great majority had been re-exposed to gluten for only three months.

The increase in IgA cells in childhood coeliac disease contrasts with the adult form of the condition in which reduced (Douglas et al, 1970; Pettingale, 1971) or normal numbers have been demonstrated Soltoft, 1970; Lancaster-Smith et al, 1974b).

A relative (Pettingale, 1971) or absolute (Douglas et al, 1970; Soltoft, 1970; Lancaster-Smith et al, 1974b) increase in IgM cells has been found in both treated and untreated adult coeliac disease as in the

\begin{tabular}{lcccc}
\hline & $\begin{array}{l}\text { Age Range } \\
(y r)\end{array}$ & IgA & $I g M$ & $I g G$ \\
\hline $\begin{array}{c}\text { Control children } \\
\text { (present study) }\end{array}$ & $5-16 \cdot 5$ & $832 \pm 40$ & $151 \pm 30$ & $53 \pm 4$ \\
$\begin{array}{c}\text { Normal children } \\
\text { (Savilahti, 1972a) }\end{array}$ & $2-16$ & $781 \pm 61$ & $196 \pm 23$ & $53 \pm 7$ \\
$\begin{array}{c}\text { Normal adults } \\
\text { (Lancaster-Smith } \\
\text { et al, 1974a) }\end{array}$ & $17-67$ & $780 \pm 47$ & $200 \pm 18$ & $50 \pm 9$ \\
\hline
\end{tabular}

Table III Jejunal immunoglobulin-containing cells in normal children-a comparison with previous studies

Cells $/ \mathrm{mm}^{2}$ means $\pm \mathrm{SE}$ 
currently studied children. Savilahti (1972b), however, was able to show that IgM cell numbers in his coeliac children returned to normal on a strict in-patient gluten-free diet. It is possible, therefore, that the raised IgM cell counts in our treated patients and in those of other workers, the great majority of whom were treated as outpatients, were due to small amounts of gluten being inadvertently consumed despite the presence of very thorough dietary assessment and advice. If this is the explanation for the raised IgM cell numbers in the presence of normal IgA cell counts, it would imply that the IgM system is the more sensitive to small amounts of gluten or other antigens entering the jejunal mucosa. Alternatively, as Savilahti (1972b) suggests, the IgA system may become exhausted as the patient progresses into adult life, leading to a compensatory increase in IgM cells, although, like Savilahti, we did not demonstrate any correlation between immunoglobulin-containing cell numbers and age of patients to support this hypothesis.

The increase in IgG cells in untreated patients is in accord with previous findings in both adult (Soltoft, 1970; Lancaster-Smith et al, 1974b) and childhood (Savilahti, 1972b) coeliac disease. We have also confirmed that the IgG cell numbers are within the normal range in patients on gluten-free diets (Savilahti, 1972b; Lancaster-Smith et al, 1974b). The numbers of IgG cells, however, are relatively small, constituting only $6 \%$ of the total in this study and are not thought to be of major importance in local immunological reactions.

Immunoglobulin-containing cell populations have not been quantitated in previously treated coeliac children studied serially before and after reintroduction of gluten to the diet. This study clearly demonstrates that all three classes of cells increase during three months' re-exposure to gluten. Expressed as a percentage of the total increase of immunoglobulin-containing cells, IgA cells accounted for $64 \%$ of the rise, IgM for $30 \%$, and IgG for only $6 \%$. However, expressed as a proportion of each class of cell, the increase was approximately twice as great for $\operatorname{IgM}(38 \%)$ as for $\operatorname{IgA}(22 \%)$. These findings are similar to those found in adult disease (Lancaster-Smith et al, 1974a) and suggest that both IgA and IgM systems are important in the pathogenesis of the intestinal lesion in childhood coeliac disease. This is additionally supported by the correlation between the severity of the mucosal lesion and the extent of $\operatorname{IgA}$ and $\operatorname{IgM}$ cell increases.

Staining of the basement membrane region of the jejunal mucosa with anti-IgA serum in coeliac children is in agreement with the observations of Shiner and Ballard (1972) and may, as these authors suggest, indicate immune-complex deposition. Alter- natively, this staining could be due to IgA produce in excess in the coeliac mucosa, becoming non ${ }^{-}$ specifically attached to connective tissue in the basement membrane region. We have not confirmed the presence of complement in this region as reporteff in a proportion of children studied by Shiner and Ballard (1972) and in adults studied by Doe et $a \bar{\Phi}$ (1974). Complement deposition and its detection however, are probably critically dependent uporf dose of antigen and the timing of biopsy, both of $\vec{p}$ which in our study varied a great deal from those employed by these other workers.

As might have been anticipated from previous studies (Immonen et al, 1966; Savilahti, 1972b) excluding this patient with $\operatorname{IgA}$ deficiency, serume concentrations of IgA tended to be higher in un- $-\mathrm{v}$ treated than in treated patients or controls, althoughe these differences did not reach statistical significance The normal number of IgA cells, albeit only jus? within the normal range in the patient with serum IgA deficiency, suggests that disparity can exis between systemic and local immunological status. $\vec{A}$

Normal serum IgM concentrations are in accord with previous findings in childhood coeliac disease (Savilahti, 1972b) but differ from adult coeliacs ino whom low concentrations occur (Hobbs et al., 1969) due to defective total body synthesis (Brown et al 1969). The significant fall in IgM concentrations in our children after reintroduction of gluten to the die has been observed in five out of six coeliac childrer $\vec{B}$ studied by Alp and Wright (1971). If this phenomenon in children is also due to a defective total bodye synthesis of IgM the increased activity of the gut IgMP. system, as demonstrated in coeliac disease by this and other immunofluorescent studies (Douglas et al $\bar{l}_{;}^{\circ}$ 1970; Soltoft, 1970; Lancaster-Smith et al, 1974b and by tissue culture (Loeb et al, 1971; Falchuk and Strober, 1974), obviously does not compensate sufficiently to maintain serum concentrations of IgM. This may be because the gut IgM response is comparatively insignificant in relation to the defecto in total body synthesis or because excess IgME. produced in the coeliac gut does not pass into the general pool but is consumed locally in mucosah immunological reactions.

This study confirms abnormalities of immuno- globulin-containing cells in the jejunal mucosa in children with untreated coeliac disease (Savilahti 1972b). It has also clearly been shown that there is as pronounced small intestinal IgA and IgM celf response to the reintroduction of gluten to the diet $\frac{0}{0}$ In addition, staining of the epithelial basement苑 membrane region with anti-IgA serum may implicat $\frac{?}{\mathbb{P}}$ this immunoglobulin in the pathogenesis of the mucosal lesion. On the other hand, the greater proportional increase of IgM cells and the fall ing 
serum concentrations of IgM after re-exposure to dietary gluten suggests that this class of immunoglobulin is also involved. These observations are of added interest in view of the recent demonstration that approximately half the $\operatorname{IgA}$ and $\operatorname{IgM}$ produced by the coeliac jejunum in response to gluten challenge is antigliadin antibody (Falchuk and Strober, 1974).

SP and JTH gratefully acknowledge the support of The Wellcome Trust; SP also acknowledges the support of The British Council. We thank Dr M. L. Clark for his help and The Action Research for the Crippled Child who assisted in financing this project. We also thank Professor Soothill for estimating the serum immunoglobulin levels. ML-S was on an elective research period from The London Hospital.

\section{References}

Alp, M. H. and Wright, R. (1971). Autoantibodies to reticulin in patients with idiopathic steatorrhoea, coeliac disease and Crohn's disease and their relation to immunoglobulins and dietary antibodies. Lancet, 2, 682-685.

Brown, D. L., Cooper, A. G., and Hepner, G. W. (1969). IgM metabolism in coeliac disease. Lancet, 1, 858-861.

Crabbé, P. A., Carbonara, A. O., and Heremans, J. F. (1965). The normal human intestinal mucosa as a major source of plasma cells containing $\gamma \mathrm{A}$ immunoglobulins. Lab. Invest., 14, 235-248.

Crabbé, P. A. and Heremans, J. F. (1966). The distribution of immunoglobulin-containing cells along the human gastrointestinal tract. Gastroenterology, 51, 305-316.

Doe, W. F., Henry, K., and Booth, C. C. (1974). Complement in coeliac disease. In Coeliac Disease: Proceedings of the 2nd International Coeliac Symposium, Leyden, edited by W. T. J. M. Hekkens and A. S. Pena. Stenfert Kroese, Leyden.

Douglas, A. P., Crabbé, P. A., and Hobbs, J. R. (1970). Immunochemical studies of the serum, intestinal secretions and intestinal mucosa in patients with adult celiac disease and other forms of the celiac syndrome. Gastroenterology, 59, 414-425.

Falchuk, Z. M. and Strober, W. (1974). Gluten-sensitive enteropathy: synthesis of antigliadal antibody in vitro. Gut, 15, 947-952.

Hobbs, J. R., Hepner, G. W., Douglas, A. P., Crabbé, P. A., and Johansson, S. G. O. (1969). Immunological mystery of coeliac disease. (Letter). Lancet, 2, 649-650.

Holmes, G. K. T., Asquith, P., Stokes, P. L., and Cooke, W. T. (1974). Cellular infiltrate of jejunal biopsies in adult coeliac disease in relation to gluten withdrawal. Gut, 15, 278-283.

Immonen, P., Kouvalainen, K., and Visakorpi, J. K. (1966). The immunoelectrophoretic $\gamma \mathrm{A}$ globulin in malabsorption. Ann. paediat. (Basel), 207, 269-276.

Lancaster-Smith, M., Kumar, P. J., and Clark, M. L. (1974a). Immunological phenomena following gluten challenge in the jejunum of patients with adult coeliac disease and dermatitis herpetiformis. In Coeliac Disease: Proceedings of the 2nd International Coeliac Symposium, Leyden, edited by W. T. J. M. Hekkens and A. S. Pena. Stenfert Kroese, Leyden.

Lancaster-Smith, M., Kumar, P. J., Marks, R., Clark, M. L., and Dawson, A. M. (1974b). Jejunal mucosal immunoglobulin-containing cells and jejunal fluid immunoglobulins in adult coeliac disease and dermatitis herpetiformis. Gut, 15, 371-376.

Lancaster-Smith, M., Kumar, P. J., Dawson, A. M., (1975). The cellular infiltrate of the jejunum in adult coeliac disease and dermatitis herpetiformis following reintroduction of dietary gluten. Gut, 16, 683-688.

Loeb, P. M., Strober, W., Falchuk, Z. M., and Laster, L. (1971). Incorporation of L-leucine ${ }^{14} \mathrm{C}$ into immunoglobulins by jejunal biopsies of patients with celiac sprue and other gastrointestinal diseases. J. clin. Invest., 50, 559-509.

McNeish, A. S., Rolles, C. J., and Thompson, R. A. (1974). Evidence of complement activation after gluten challenge in treated coeliac children. In Coeliac Disease: Proceedings of the 2nd International Coeliac Symposium, Leyden, edited by W. T. J. M. Hekkens and A. S. Pena. Stenfert Kroese, Leyden.

Pettingale, K. W. (1971). Immunoglobulin-containing cells in coeliac syndrome. Gut, 12, 291-296.

Savilahti, E. (1972a). Immunoglobulin-containing cells in the intestinal mucosa and immunoglobulins in the intestinal juice in children. Clin. exp. Immunol., 11, 415-425.

Savilahti, E. (1972b). Intestinal immunoglobulins in children with coeliac disease. Gut, 13, 958-964.

Shiner, M. and Ballard, J. (1972). Antigen-antibody reactions in jejunal mucosa in childhood coeliac disease after gluten challenge. Lancet, 1, 1202-1205.

Soltoft, J. (1969). Immunoglobulin-containing cells in normal jejunal mucosa and in ulcerative colitis and regional enteritis. Scand. J. Gastroent., 4, 353-360.

Soltoft, J. (1970). Immunoglobulin-containing cells in nontropical sprue. Clin. exp. Immunol., 6, 413-420. 